\title{
Benign Bone Neoplasm
}

National Cancer Institute

\section{Source}

National Cancer Institute. Benign Bone Neoplasm. NCI Thesaurus. Code C4880.

A neoplasm that arises from the bone or articular cartilage and does not invade adjacent tissues or metastasize to other anatomic sites. 